enzyme mRNAs involved in SPM synthesis. Even more striking was a pronounced effect of Tr14 at 12-36 hours on Fpr1 and Fpr2 mRNAs, which are the transmembrane receptors for the SPM lipid mediators. Consistent with elevated levels of enzymes regulating SPM synthesis, and SPR receptors, there was a noticeable decrease in the mRNA levels of the p65/RelA subunit of NFkB at 7296 hours. NFkB is a critical transcription factor in inflammation, regulating numerous cytokines and chemokines.

Conclusions: Tr14 and diclofenac had very different effects on the SPM synthetic pathway after cutaneous wounding. Tr14 stimulated mRNA levels of several key regulators of SPM synthesis, and had a marked effect on the mRNA levels of the SPM receptors. Tr14, not diclofenac, suppressed mRNA levels for NFkB subunit p65/RelA, which may explain some of the anti-inflammatory and proresolving properties of Tr14.

Disclosure of Interest: None declared

DOI: 10.1136/annrheumdis-2018-eular.3789

\section{AB0081 LOW LIPOCALIN-2 IN SYSTEMIC LUPUS ERYTHEMATOSUS PREGNANCIES- A POSSIBLE MECHANISM FOR LOSS OF TOLERANCE}

T.T. Pedersen ${ }^{1}$, M.H. Fenstad ${ }^{2}$, B. Jakobsen ${ }^{1}$, H.S. Koksvik ${ }^{1}$, T.S. Moksnes ${ }^{1}$, M. Wallenius ${ }^{1}$, T.H. Flo ${ }^{3}$, M. Haug ${ }^{3} .{ }^{1}$ Norwegian National Advisory Unit on Pregnancy and Rheumatic diseases; ${ }^{2}$ Dept. of Immunology and Transfusion Medicine, St. Olavs Hospital; ${ }^{3}$ Centre of Molecular Inflammation Research and Dept. of Clinical and Molecular Medicine, NTNU, Trondheim, Norway

Background: Lipocalin-2 (LCN2) has become increasingly relevant as a potential clinical biomarker of rheumatic diseases. ${ }^{1}$ The biological role of LCN2 in the adaptive immunity is less understood. It has been shown that LCN2 can induce immune tolerance by upregulation of human leukocyte antigen G (HLA-G) expression and by expansion of T-regulatory cells. ${ }^{2}$ LCN2-deficient mice have been found to be more susceptible to induction of autoimmunity. ${ }^{3}$ Systemic lupus erythematosus (SLE) is a disease associated with loss of tolerance. Pregnancy complications seen in SLE are also regarded as a consequence of immune dysregulation. LCN2 might therefore play a role as an immune modulator in SLEpregnancies.

Objectives: The study objective was to obtain a better understanding of immune regulation in pregnant women with SLE. In this study, we analysed serum LCN2 and clinical parameters in women with RA, SLE and healthy controls during pregnancy and postpartum.

Methods: The Norwegian National Advisory Unit on Pregnancy and Rheumatic Diseases collects serum samples in a biobank from women with inflammatory rheumatic diseases. Samples were obtained before pregnancy, in each trimester and 6 weeks, 6 months and 12 months postpartum from pregnant women with SLE $(n=28), R A(n=34)$ and healthy pregnant controls $(n=19)$. A sandwich ELISA was used to measure LCN2 in the serum samples. The biobank database was linked to RevNatus, a Norwegian quality registry collecting comprehensive clinical data about these women.

Results: Our cohort of pregnant women with SLE and RA had low disease activity throughout pregnancy and $67 \%-95 \%$ used medication (table 1). LCN2 levels in serum samples from women with SLE were found significantly lower compared to samples from women with RA and healthy controls at all time-points $(p<0.05)$ (graph).

Abstract AB0081 - Table 1. Disease activity and medication

\begin{tabular}{|c|c|c|c|c|c|c|}
\hline & \multicolumn{3}{|c|}{ SLE patients } & \multicolumn{3}{|c|}{ RA patients } \\
\hline & $\begin{array}{c}1 \mathrm{st} \\
\text { trimester }\end{array}$ & $\begin{array}{c}\text { 2nd } \\
\text { trimester }\end{array}$ & $\begin{array}{c}\text { 3rd } \\
\text { trimester }\end{array}$ & $\begin{array}{c}1 \mathrm{st} \\
\text { trimester }\end{array}$ & $\begin{array}{c}\text { 2nd } \\
\text { trimester }\end{array}$ & $\begin{array}{c}\text { 3rd } \\
\text { trimester }\end{array}$ \\
\hline Disease activity & & & & & & \\
\hline $\begin{array}{l}\text { LAI-P Mean (range) } \\
\text { [SD] }\end{array}$ & $\begin{array}{c}0,04(0- \\
0,25) \\
{[0,08]}\end{array}$ & $\begin{array}{c}0,02(0- \\
0,16) \\
{[0,05]}\end{array}$ & $\begin{array}{c}0,005 \\
(0-0,08) \\
{[0,02]}\end{array}$ & & & \\
\hline $\begin{array}{l}\text { DAS28 Mean } \\
\text { (range) [SD] }\end{array}$ & & & & $\begin{array}{c}2,34 \\
(1,79- \\
3,91) \\
{[0,76]}\end{array}$ & $\begin{array}{c}2,57 \\
(1,42- \\
5,02) \\
{[1,06]}\end{array}$ & $\begin{array}{c}2,57 \\
(1,79- \\
4,90) \\
{[0,94]}\end{array}$ \\
\hline Medication & & & & & & \\
\hline $\begin{array}{l}\text { Prednisolone, } \\
\text { receiving (\%) (dose } \\
\text { range }[\mathrm{mg}] \text { ) }\end{array}$ & $\begin{array}{c}17(2,5- \\
7,5)\end{array}$ & $\begin{array}{c}48(2,5- \\
7,5)\end{array}$ & $\begin{array}{c}48(2,5- \\
10)\end{array}$ & $\begin{array}{c}28(2,5- \\
10)\end{array}$ & $\begin{array}{c}33(2,5- \\
15)\end{array}$ & $\begin{array}{c}38(2,5- \\
12,5)\end{array}$ \\
\hline $\begin{array}{l}\text { Other } \\
\text { immunesupressive } \\
\text { receiving }\left(>1^{*}\right)(\%)\end{array}$ & $96(33)$ & 91 (39) & $95(43)$ & $67(11)$ & $76(5)$ & $80(10)$ \\
\hline
\end{tabular}

* $>1$ : more than one of the following: SLE: hydroxychloroquine; azathioprine, RA: sulfasalazine, methotrexate, hydroxychloroquine, TNF inhibitors

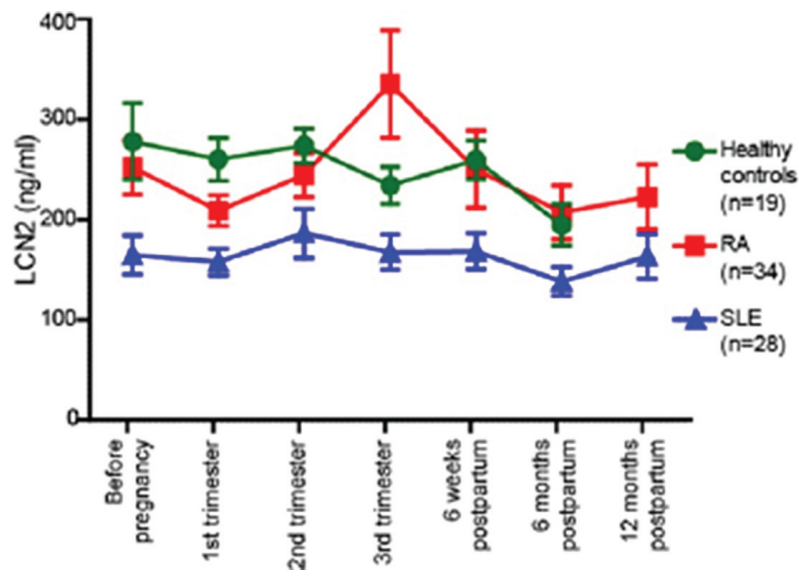

Abstract AB0081 - Figure 1

Conclusions: Pregnant women with SLE had lower levels of LCN2 compared to pregnant women with RA and healthy controls. Our cohort of women had well controlled disease, making it likely that our findings represent inherent biological differences rather than effects of disease activity. Low LCN2 levels can be a possible mechanism for loss of tolerance seen in SLE patients during pregnancy.

\section{REFERENCES:}

[1] Abella V. Biomarkers 2015;20(8):565-71.

[2] La Manna G. PLoS One 2014 Feb 27;9(2).

[3] Pawar RD. Clin Immunol 2014 Sep;154(1):49-65.

Acknowledgements: This study is supported by grants from St. Olavs Hospital and Norsk Revmatikerforbund.

Disclosure of Interest: None declared

DOI: 10.1136/annrheumdis-2018-eular.3637

\section{AB0082 CLINICALLY RELEVANT DISCREPANCIES BETWEEN DIFFERENT RHEUMATOID FACTOR ASSAYS}

W. Falkenburg ${ }^{1,2}$, H. von Richthofen ${ }^{1}$, J. Koers ${ }^{1}$, C. Weykamp ${ }^{3}$, M. Schreurs ${ }^{4}$, L. Bakker-Jonges ${ }^{5}$, I.-A. Haagen ${ }^{6}$, W. Lems ${ }^{7}$, D. Hamann ${ }^{8}$, D. van

Schaardenburg ${ }^{7}$, T. Rispens ${ }^{1} .{ }^{1} /$ mmunopathology, Sanquin Research;

${ }^{2}$ Rheumatology, Amsterdam Rheumatology and immunology Center, Amsterdam;

${ }^{3}$ Queen Beatrix Hospital, Winterswijjk, ${ }^{4}$ Erasmus MC University Medical Center,

Rotterdam; ${ }^{5}$ Reinier de Graaf Groep, Delft, ${ }^{6}$ Onze Lieve Vrouwe Gasthuis;

${ }^{7}$ Amsterdam Rheumatology and immunology Center, ${ }^{8}$ Sanquin Research,

Amsterdam, Netherlands

Background: Accurate measurements of rheumatoid factors (RFs), autoantibodies binding IgG, are important for diagnosing rheumatoid arthritis (RA) and for predicting disease course. Worldwide, various RF assays are being used that differ in technique and target antigens.

Objectives: To study whether assay choice leads to clinically important discrep ancies in RF status and level.

Methods: RF measurements using 4 commercial RF assays were compared in $32 \mathrm{RF}^{+}$samples. Using ELISAs, the influence of the target antigen source-human $\lg G$ (hlgG) versus rabbit $\lg G$ (rlgG) — on measured RF levels was investigated in arthralgia patients and RA patients.

Results: Substantial discrepancies were found between RF levels measured in the four commercial assays. 6 samples (19\%) with RF levels below or slightly above the cut-off in an rlgG-based assay were $\mathrm{RF}^{+}$in three assays using hlgG as the target antigen, some with very high levels. Direct ELISA comparisons of RF reactivity against $\mathrm{hlgG}$ and $\mathrm{rlgG}$ estimated that among $173 \mathrm{ACPA}^{+}$arthralgia patients, originally RF negative in rlgG-based assays, up to $10 \%$ were single positive against hlgG. Monoclonal RFs binding to hlgG and rlgG or hlgG only supported these findings. In a cohort of 69 early RA patients, virtually all RF responses reacted with both targets, although levels were still variable.

Conclusions: The use of RF assays that differ in technique and target antigen, together with the different specificities of RF responses, leads to discrepancies in RF status and levels. This has important consequences for patient care if RA diagnosis and disease progression assessments are based on RF test results.

Disclosure of Interest: None declared

DOI: 10.1136/annrheumdis-2018-eular.1477 